\title{
Sodobni pregled slovanske filologije
}

\author{
Andreja Žele
}

Cobiss: 1.19

Aleksandr Dmitrievič Duličenko, Osnovy slavjanskojfilologii 1: istoriko-ètnografičeskaja i ètnolingvističeskaja problematika, 2: lingvističeskaja problematika, Opole: Uniwersytet Opolski - Instytut Filologii Polskiej Opolskie Towarzystwo Przyjaciół Nauk, $2011,526+640$ str.

Zelo obsežno delo Osnove slovanske filologije Aleksandra Dmitrijeviča Duličen$\mathrm{ka}$, mednarodno znanega tartujskega filologa, na dobrih 1150 straneh $\mathrm{v}$ dveh delih (Zgodovinsko-etnografska in etnolingvistična problematika in Jezikoslovna problematika) je velikopotezen in kompleksen kulturološko-jezikovno-jezikoslovni popis slovanske filologije, zlasti jezikoslovnih usmeritev slavistike, $\mathrm{z}$ vidika sodobnih ugotovitev na prelomu drugega in tretjega tisočletja. Avtor namreč skuša zajeti tako osnovni jezikovni razvoj kot aktualno stanje vzhodnih, zahodnih in južnih slovanskih jezikov. Organsko so opisu pridružene še kulturne in politične okoliščine.

Posebna odlika dela, zaradi katere je tudi tako obsežno, je vključitev tako rekoč vseh obstoječih slovanskih jezikov in ustrezno primerjalno vključevanje tudi že izumrlih jezikov, kot sta npr. polabščina, slovinščina ipd. Ne ostane prikrito, da so avtorjeva specialnost slovanski knjižni mikrojeziki kot kašubščina, lužiška srbščina, rezijanščina, rusinščina ipd. Zlasti vidika etnogeneze in primerjalno-tipološke obravnave slovanskih jezikov sta $\mathrm{v}$ avtorjevi večdesetletni raziskavi spodbudila, omogočila in potrdila tudi nekaj avtorske terminologije kot npr. slovanski knjižni mikrojezik ali lingvonim v smislu ustaljenega poimenovanja za posamezni slovanski jezik. Po mnenju obeh recenzentov, V. M. Mokijenka in Władysława Lubaśa, lahko tako široko tematsko zastavljeno delo v smislu nove sinteze razvoja in stanja slavistike prevzame tudi vlogo enciklopedije sodobne slavistike.

Ta enciklopedični obseg popisov oz. pregledov, zbranih opredelitev in avtorjevih komentarjev je sestavljen iz petnajstih poglavij s povprečnim obsegom po osemdeset strani:

1. del:

(1) Slovanska filologija, njena zgradba in mesto v vedi o Slovanih - slavistiki (slovanoslovju) / Славянская филология, ее структура и место в науке о словянах - славистике (славяноведении), 
(2) Pomembnejše prelomnice v razvoju slovanske filologije v slovanskih državah / Важнейшие вехи в развитии славянской филологии в славянских странах,

(3) Pregled sodobnega slovanstva / Обозрение современного славянства,

(4) Slovanska etnogeneza in najstarejši naselitveni prostor Slovanov (slovanska pradomovina) / Славянский этногенез и древнейшие места обитания славян (славянская прародина),

(5) Slovani $v$ davnini z zgodovinskega in etnolingvističnega vidika (po pričevanju pisnih spomenikov, ljudske kulture in jezika) / Славяне в древности в историческом и этнолингвистическом аспекте (по данным письменных памятников, традиционной культуры и языка),

(6) Slovanska etnonimika / Славянская этнонимика,

(7) Slovanska lingvonimika / Славянская лингвонимика,

(8) Slovanska interlingvistika: o slovanski vzajemnosti in vseslovanskem jeziku v zgodovini Slovanov / Славянская интерлингвистика: идея славянской взаимности и всеславянского языка в истории славян,

(9) Slovanska pismenost, staroslovanski in starocerkvenoslovanski jezik / Славянская письменность, старославянский и церковнославянский языки;

2. del:

(10) Izvor slovanskih jezikov (slovanska glotogeneza) / Происхождение славянских языков (славянский глоттогенез),

(11) Razpad praslovanskega jezika, ločitev slovanskih jezikov in njihova razvrstitev / Распад праславянского языка, выделение славянских языков и их классифокация,

(12) Jeziki sodobnih slovanskih narodov / Языки современных славянских наций,

(13) Slovanska mikrolingvistika: slovanski knjižni mikrojeziki / Славянская микролингвистика: славянские литературные микроязыки,

(14) Slovanski jeziki v primerjalno-tipološki obravnavi / Славянские языки в сравнительно-типологическом освещении,

(15) O izgubljenih slovanskih jezikih / Об утраченных славянских языках.

Temu sledijo še tri priloge, in sicer pomembnejše periodične in serijske publikacije (med temi je navedena tudi Slavistična revija), slovar slovanskih lingvonimov in preglednica jezikoslovnih dogodkov pri Slovanih, sledi še imenski seznam vključenih raziskovalcev - jezikoslovcev s pripisano stranjo omembe.

Že našteti naslovi poglavij dovolj povedno nakazujejo, da bi vsaj nekatera izmed njih potrebovala oz. zaslužila problemsko-kritično obravnavo. Za informativno poročilo je mogoče dovolj poudariti nekaj za nas aktualnejših vsebin, za oceno ali celo za recenzijski članek pa bi bilo potrebno poglobljeno in analitično branje posameznih izbranih poglavij.

$\mathrm{V}$ tem poročilu lahko le opozorim na poglavja oz. podpoglavja, in še to samo $\mathrm{z}$ vidika redkih ali koristnih podatkov. $\mathrm{V}$ podpoglavjih 2.5.3, 3.2.3.7,12.4.3 in 13.7.4 lahko preverimo opis Slovencev in slovenščine: tako je v poglavju 2 na kar desetih straneh predstavljen razvoj slovenskega knjižnega jezika in njegovo vključevanje v slovansko filologijo; v poglavju 3 je pri pregledu »sodobnega slovanstva« 
(современное славянство) na kratko opisana zgodovina preoblikovanja Slovencev v narod, od naselitve do današnjega družbenopolitičnega statusa; v poglavju 12 je kratka povzemalna predstavitev slovenščine; v poglavju 13 je kot mikrojezik posebej predstavljena prekmurščina. Tudi sicer je poglavje 13 posvečeno opisu pojava knjižni mikrojezik in posledično tudi obstoječim mikrofilologijam. V poglavju 11 je obravnavan razpad praslovanščine s pomembnejšimi zunanjimi in notranjimi dejavniki. Zagotovo je eno izmed aktualnih poglavij za vse Slovane, ki ni samo pregledno, ampak tudi avtorsko komentirano, poglavje 14; jezikoslovno pomembno je zaradi avtorjevega primerjalno-kontrastivnega pregleda jezikovnih kategorij in jezikovnih ravnin. Podpoglavje 14.3 obravnava leksikalnopomenske procese in razvojne težnje sodobnih slovanskih jezikov. Poudarjeno je vprašanje ločevanja med že normirano in ustaljeno leksiko, neologizmi in okazionalizmi oz. priložnostnicami. Na eni strani poteka proces pomenskega zastarevanja leksike, na drugi strani pa proces pomenske revitalizacije v določenem obdobju že izgubljenih leksemov. Vedno sta prisotni tudi t. i. ideologizacija in prevladujoča angloamerikanizacija, še zlasti na tehnično-tehnološkem področju in na področju množične kulture. Opazne so močne besedotvorne težnje k zlaganju, stalno še narašča tudi obseg besednozveznih leksemov, kar besedotvorno in pomenotvorno spreminja slovansko leksiko. V povezavi s tovrstnimi ugotovitvami je poudarjena pomembnost stalnega posodabljanja virov, pomembno je tudi stalno razvijanje oz. dopolnjevanje metod.

Zadnje poglavje odkriva razvojne perspektive slovanskih jezikov in v zvezi s tem je opozorjeno na bistveno razliko med razvojnim zbliževanjem jezikov na eni strani in razvojnim razdruževanjem na drugi; razvojna razdruževanja potekajo npr. med češčino in slovaščino ter med srbščino, hrvaščino, bosanščino in črnogorščino. Čedalje bolj pa je mogoče zaznavati postopno razvojno vplivanjsko nadvlado ruščine nad ukrajinščino in beloruščino. Tudi med knjižnimi mikrojeziki avtor ločuje funkcionalno močnejše, kot sta npr. zgornja lužiščina in rusinščina, srednje funkcionalno aktivne, kot sta npr. gradiščanska hrvaščina in kašubščina, in funkcionalno že oslabljene, kot je npr. rezijanščina.

Avtor je med drugim zbral večino relevantnih filoloških in jezikoslovnih pojmov, jih ovrednotil, in poimenovalni odraz tega je najobsežnejši slovar slovanskih lingvonimov doslej (900 enot). Vsi pojmi so postavljeni v medsebojna razmerja: tako je npr. slovanska filologija obravnavana kot del slavistike oz. slovanoslovja; v izhodišče slovanoslovja pa je postavljena paleoslavistika.

Naj bo to poročilo zgolj namig za podrobnejši pretres in komentar posameznih poglavij. Vsekakor je to delo dragocen vir raznovrstnih slavističnih informacij in hkrati solidno izhodišče za vse nadaljnje dopolnitve ali za nova nastajajoča tovrstna dela. 